\title{
Reproductive strategy of spiny gurnard Lepidotrigla dieuzeidei Blanc and Hureau, 1973 from the south-eastern Adriatic Sea
}

\author{
Tatjana DOBROSLAVIĆ ${ }^{*}$, Alexis CONIDES ${ }^{2}$, Jadranka SULIĆ ŠPREM ${ }^{3}$, \\ Branko GLAMUZINA ${ }^{1}$ and Vlasta BARTULOVIĆ ${ }^{1}$ \\ ${ }^{1}$ University of Dubrovnik, Department of Applied Ecology, Ćira Carića 4, Dubrovnik, Croatia \\ ${ }^{2}$ Hellenic Centre for Marine Research, 46.7 km Athens-Sounion, Anavyssos, Greece \\ ${ }^{3}$ Dubrovnik Natural History Museum, Dubrovnik, Croatia \\ *Corresponding author: tatjana.dobroslavic@unidu.hr
}

This study provides the first data on the reproductive biology of the spiny gurnard Lepidotrigla dieuzeidei. A total of 1027 individuals were collected monthly from September 2011 to August 2012. The total length of the individuals in the sample ranged from $7.46 \mathrm{~cm}$ to $14.62 \mathrm{~cm}$ with a female to male ratio of 1 to 0.59. Positive allometric growth was observed for both females $(b=3.07)$ and males $(b=3.08)$. Variations of condition factor were similar in both sexes with mean values of 1.07 for females and 1.01 for males. The fish L. dieuzeidei had a long spawning period extending from November to July based on monthly values of gonadosomatic index. Histological analysis showed that this fish was multiple synchronous developments of ovaries with multiple spawning events. The ovaries were always represented with a group of primary oocytes and a diverse population of vitellogenic oocytes, each specially recruited during the final stages of maturation in uniform or uneven phases. Batch fecundity was estimated gravimetrically using the hydrated oocyte method and was estimated to be around 558 to 10.230 oocytes per female. L. dieuzeidei is an important by-catch species and data from this study represent a valuable contribution to stock management

Key words: oogenesis; spermatogenesis; gonad maturation; fecundity; oocyte diameter; multiple spawning fishes

\section{INTRODUCTION}

Fisheries of deeper Adriatic Sea waters are mainly executed at depths of 200-300 $\mathrm{m}$ and it represents the largest area of occurrence of demersal shared stocks in the Mediterranean. Many different fishing gears exploit the demersal communities but trawl net represents the main gear in terms of catch and fleet power (CADDY, 1993; SÁNCHEZ et al., 2007). However, trawling exploitation in the Adriatic Sea is directed at a restricted number of target species. The main target fish species for the demersal trawl fishery are European hake (Merluccius merluccius), red mullet (Mullus barbatus barbatus), breams (Pagellus spp.), whiting (Merlangius merlangus), anglerfish (Lophius spp.), flatfish (Solea solea, Scophthalmus maximus, Scophthalmus rhombus, Platichthys flesus).

Studies of the impact of fishing have mostly focused on the target and economically important species and little is known about the impact 


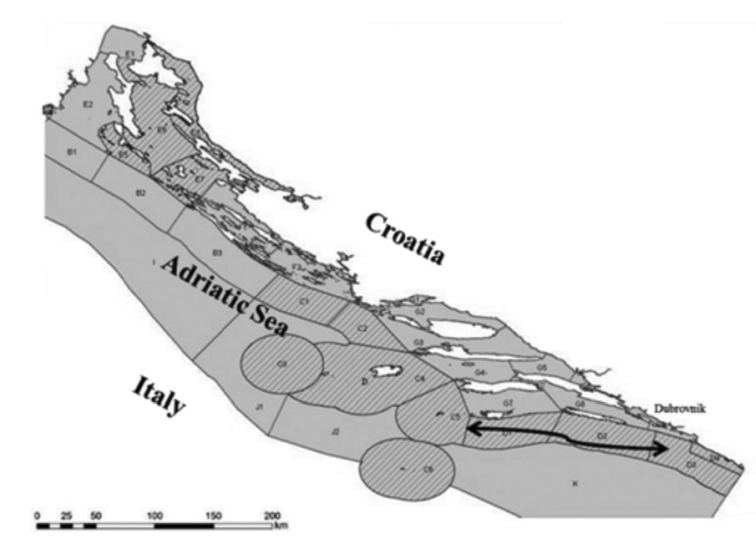

Fig. 1. Location of commercial fishing from town Dubrovnik to the north point of Pelješac peninsula (line), southern Adriatic Sea

to non-target species that have none or small economic value and have been characterized as by-catch species. One of the frequent by-catch species is spiny gurnard Lepidotrigla dieuzeidei Blanc \& Hureau, 1973 from the family Triglidae. It is a small benthic species distributed in the eastern Atlantic and the western and middle Mediterranean Sea and it prefers sandy and muddy bottoms at a depth between 60 and $180 \mathrm{~m}$ (JARDAS, 1996). There are around 114 species of family Triglidae in the world and only 8 species divided into 5 genera exist in the Mediterranean and the Adriatic Sea. L. dieuzeidei and largescaled gurnard, L. cavillone are the only representatives of the genus Lepidotrigla. Despite the high abundance of gurnard species, little is known about the biology of $L$. dieuzeidei, especially reproduction data. For the Adriatic Sea, only available data for this species is an elliptic analysis of otoliths (MONTANINI et al., 2010).

Previous studies in other parts of the Mediterranean are based on the first record with the morphometric and meristic description of this species (ERYILMAZ, 2002; BAÑÓN, 2004; DALYAN \& ERYILMAZ, 2006). The weight-length relationship was investigated in the Mediterranean (TORRES et al., 2012; BAŞUSTA et al., 2013a) and in the south coast of Portugal (OLIM \& BORGES, 2006) while the age and growth and relationship between total length and otoliths dimensions were analysed in the northeast Mediterranean (BAŞUSTA et al., 2013b; BAŞUSTA et al., 2017).
Considering the lack of crucial biological data for this species, the main objective of this study was to investigate the annual reproductive cycle of $L$. dieuzeidei in the Adriatic Sea. Sex ratio, length at sexually maturity, gonadosomatic index, fecundity, gonad development and oocyte size were analysed to obtain insight into the spawning activity for this by-catch species. Knowledge of reproductive biology of a fish species is essential for stock assessment and effective fishery management.

\section{MATERIAL AND METHODS}

\section{Sampling site, procedure and measurements}

Samples were collected from south Croatian offshore waters between the city of Dubrovnik and the north point of Pelješac peninsula (Fig. 1). A total of 1027 individuals were collected monthly, from September 2011 to August 2012. Specimens were caught at depths between 170 and $230 \mathrm{~m}$ using bottom trawl net (2 hauls, each lasted for approximately $5 \mathrm{~h}$ ) during commercial fishing activities (vessel engine power $60 \mathrm{kw}$ ). The total length of the net was $45 \mathrm{~m}$ with a mesh size of $60 \mathrm{~mm}$ and cod-end 24 $\mathrm{mm}$, measured knot to knot. After catching all specimens were put on ice and transported to the laboratory for further analysis. For each fish, total length (Lt) was measured using a simple calliper to the nearest $0.1 \mathrm{~mm}$ and weighed (W) to the nearest $0.1 \mathrm{~g}$. Fishes were gutted, and gonads were removed and weighed $(\mathrm{Wg})$ with three decimal accuracy. Sex was determined by macroscopic observation of the gonads (MACER, 1974). To test differences in relation to the expected ratio $1: 1$, the sex ratio was examined using Chi-square $(\chi 2)$ test with a probability level of 0.05 . Age was estimated by interpreting growth rings on otoliths from 200 individuals. After removal otoliths were cleaned in distilled water, immersed in glycerol and examined with stereomicroscope on a black background under reflected light. Some otoliths were polished with sandpaper (type P220 and P80) due to calcium accumulation. Age estimations were made by three readers if the readings did not coincide 
the otolith was rejected. Transparent and opaque rings were counted, one transparent and one opaque ring was considered as one year.

\section{Data analysis}

Growth was analysed using von Bertalanffy growth equation: $\mathrm{Lt}=$, where is the asymptotic length, $\mathrm{k}$ is the growth coefficient, and is the hypothetical age for $\mathrm{Lt}=0$ (TOMLINSON \& NORMAN, 1961). To describe the length-weight relationship, allometric growth equation was used: $\mathrm{W}=a^{*} L^{b}$ (RICKER, 1977), where $W$ is the total weight $(\mathrm{g}), L$ is the total length $(\mathrm{mm})$ and $a$ and $b$ are constants estimated by last square method. Fulton's condition factor was calculated following Froese (2006): $\mathrm{K}=$, where $W$ is total body weight $(\mathrm{g})$ and $L$ is the total length $(\mathrm{mm})$.

The spawning period was established based on the monthly variation of the gonadosomatic index (GSI) and calculated as GSI $=100 * \mathrm{Wg}$ / $W$, where $W \mathrm{~g}$ is gonad weight $(\mathrm{g})$ and $W$ is the total weight (g) (RICKER, 1977). To estimate size at first sexual maturity, the data were fitted in the equation: $\mathrm{P}=1 /\left(1+\mathrm{e}\left(a-b^{*} L\right)\right)$; where $\mathrm{P}$ is the probability that individuals are sexually matured, $\mathrm{L}$ is their length and $\mathrm{a}, \mathrm{b}$ coefficients. The length when $50 \%$ of analysed individuals were mature was calculated according to SPARRE \& VENEMA (1998) as $L_{50 \%}=a / b$.

For histological analysis 30 individuals, randomly selected, from both sexes were used monthly. After weighing, gonads were fixed in $8 \%$ buffered formalin. A small piece of tissue from the middle of the gonad was tested. After dehydration and clearing, tissue was embedded in paraffin, sectioned on a microtome $(5 \mu \mathrm{m})$ and stained with hematoxylin and eosin dye. All histological sections of ovaries were classified to assess the oocyte developing phase according to TYLER \& SUMPTER (1996) and BROWNPETERSON et al. (2011). Oocytes were categorized as primary growth oocyte (PG), cortical alveoli oocyte (CA), vitellogenenic oocyte (Vtg), germinal vesicle migration (GVM) and hydration (H). Atresia of oocytes was assessed according to HUNTER \& MACEWICZ (1985a). Type of ovarian development was determined according to Wal- lace and Selman (1981) and testes TAKASHIMA \& HIBIYA (1995). For quantitative analysis oocyte diameter was measured using an image analysis system (AxioVision Release 4.8. software). Male germ cells were classified as spermatogonia $(\mathrm{Sg})$, spermatocytes $(\mathrm{St})$, spermatids $(\mathrm{Sd})$ and spermatozoa (Sz) (GRIER, 1981).

It should be noted that the selection of the ovaries used for fecundity estimation was based on gonad histological sections showing that postovulatory follicles were not present. Batch fecundity was estimated gravimetrically using the hydrated oocyte method, where only oocytes larger than $500 \mu \mathrm{m}$ were counted (HUNTER et al., 1985). For each selected ovarian sample, three subsamples of $0.01 \mathrm{~g}$ from the anterior, central and posterior region of the gonad lobe were taken for counting migratory nuclei and hydrated oocytes. Batch fecundity for each female was estimated as the mean value of three subsamples that have been calculated as the number of the migratory nuclei and hydrated oocytes per unit weight of the subsample and the total weight of the gonad. Regression analyses were carried out relating fecundity to total length (Lt), total weight (W) and gonad weight (Wg). The relationships fecundity-length, fecundity-weight and fecundity-gonad weight were express by equation $\mathrm{F}=a$, where $\mathrm{F}$ is the fecundity, $X$ either $\mathrm{Lt}, \mathrm{W}$ or $\mathrm{Wg}, a$ is the constant and $b$ is the exponent (BAGENAL, 1978).

\section{Statistical analysis}

Comparison between means was performed using ANOVA test with multiple comparison tests (Tykey and Duncan) to identify similarity groups. Relations between time-series was analysed using the Cross Correlation Function (CCF) while the statistical difference between time series was analysed using the chi-square goodness of fit. Analysis of similarity between equations such as the male and female lengthweight relationships was performed using ANCOVA method. Equation fitting and all statistical analysis were performed using NCSS 11 software (NCSS 11 Statistical Software 2016). 


\section{RESULTS}

Total length (TL) of all analysed individuals $(\mathrm{n}=1027)$ ranged from 7.46 to $14.62 \mathrm{~cm}$. Both females and males were most dominant in length classes from 10 to $12 \mathrm{~cm}$. Out of 1027 analysed individuals, $642(62.5 \%)$ were females and 385 (37.5\%) males. The overall female to male ratio was 1:0.59 and chi-square analysis showed it was statistically different $\left(\chi^{2}=63.31 ; P<0.001\right)$ than the $1: 1$ ratio.

Age was successfully determined in $71.5 \%$ $(\mathrm{N}=143)$ individuals, otoliths from the remaining $28.5 \%(\mathrm{~N}=57)$ individuals were rejected because of disagreement between readers or impossibility to read otolith. The sample consisted of 77 females and 66 males. The total length of females ranged from 7.46 to $14.14 \mathrm{~cm}$ $(11.43 \pm 1.54 \mathrm{~cm})$ and males from 7.64 to 14.62 $\mathrm{cm}(10.57 \pm 1.73 \mathrm{~cm})$. In the analysed sample, the oldest individuals had 4 years, the most common ages were two $(\mathrm{N}=50)$ and three $(\mathrm{N}=51)$ with a total body length of 9.52 to $13.20 \mathrm{~cm}$. Threeyears-old females dominated in the population. The lengths-at-ages for length classes $7-14 \mathrm{~cm}$ were used to estimate the parameters of the von Bertalanffy growth equation. The estimated parameters for both males and females are given in Fig. 2. Based on the obtained growth coefficient, males growth $(k=2.51)$ faster than females $(k=2.43)$ but they had a smaller asymptotic length $(=13.64 \mathrm{~cm})$ then females $(=13.97$ $\mathrm{cm})$.

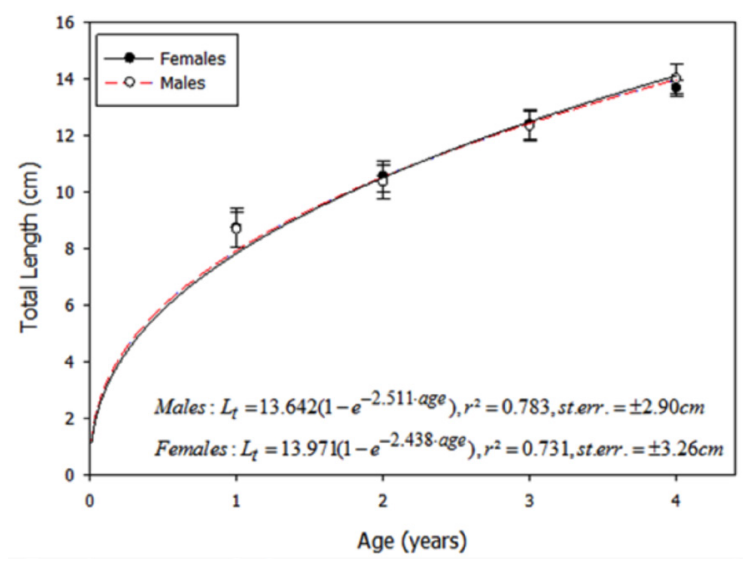

Fig. 2. von Bertalanffy growth model obtained with the lengths-at-ages data for males and females of Lepidotrigla dieuzeidei, southern Adriatic Sea
The length-weight relationships were described by the equation: $\mathrm{W}=0.009\left(\mathrm{TL}^{3.07}\right)$, $r^{2}=0.945$ and $\mathrm{W}=0.008\left(\mathrm{TL}^{3.08}\right), \mathrm{r}^{2}=0.957$ for females and males, respectively. Obtain $b$ value for both females $(b=3.07)$ and males $(b=3.08)$ showed positive allomertic growth of this species (Fig. 3).

Fluctuations of condition factor were similar in both sexes. Values ranged from 0.961 to 1.092 with a mean value of $1.075 \pm 0.04$ for females and $1.012 \pm 0.05$ for males. $\mathrm{Chi}^{2}$ goodness of fit showed that both time series show no statistical difference $(P>0.05)$, qualitatively, males showed slightly lower values. Monthly variation of condition factor showed an improved condition between April and November and lower from December to March. In both females and males, larger individuals had higher values of condition factor.

The highest gonadal activity was recorded from November to July showing the extended spawning period of this species. Average maximum values of gonadosomatic index (GSI) were recorded in April for females (8.21 $\pm 2.69 \%)$ and in December for males $(0.22 \pm 0.25 \%)$, while minimum values were recorded in August for both, females $(1.74 \pm 2.05 \%)$ and males $(0.08$ $\pm 0.06 \%$ ) (Fig. 4). Cross correlation function analysis between the two-time series showed no statistically significant interaction between sexes, the changes of male GSI did not affect or follow the changes in female GSI. The male gonads were significantly smaller than female,

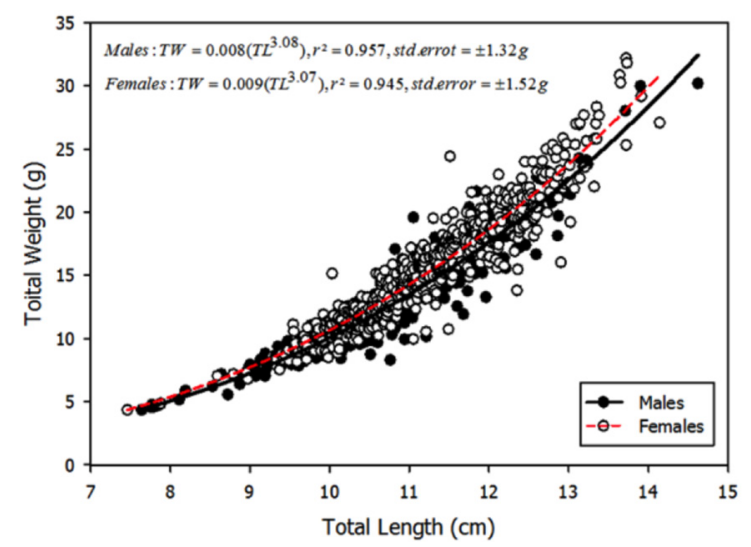

Fig. 3. The length-weight relationship for males and females of Lepidotrigla dieuzeidei, southern Adriatic Sea 




Fig. 4. Monthly variations of GSI $( \pm S D)$ for females and males of Lepidotrigla dieuzeidei, southern Adriatic Sea
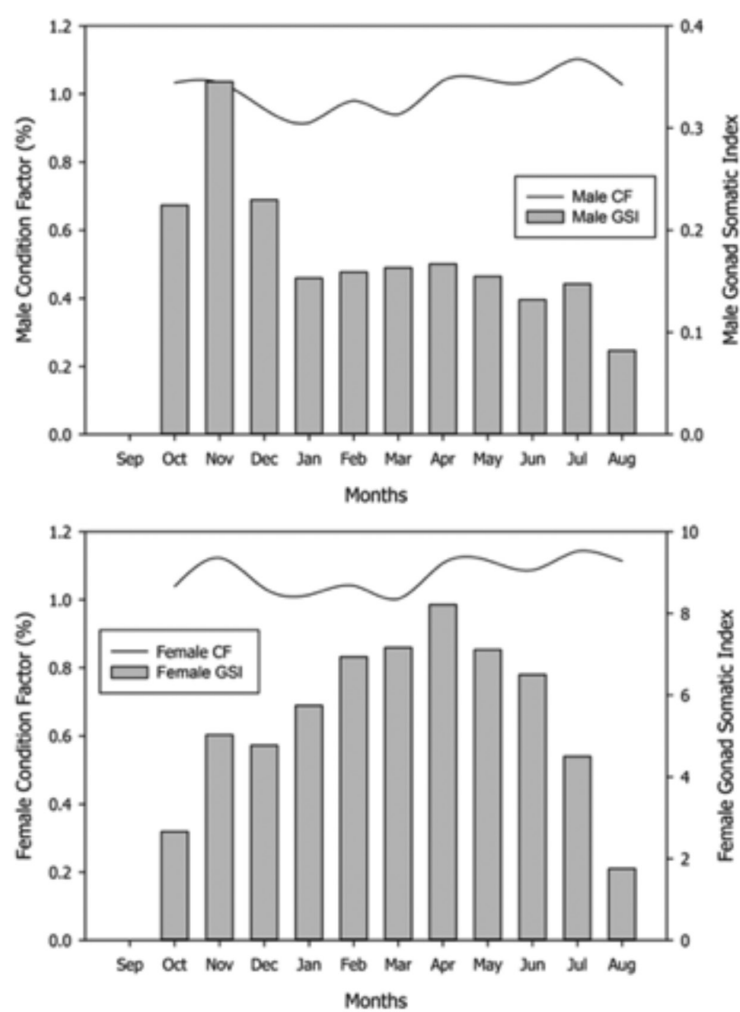

Fig. 5. Comparison between monthly values of GSI and condition factor in males and females of Lepidotrigla dieuzeidei, southern Adriatic Sea

the average weight of male gonads was 0.02 $\pm 0.01 \mathrm{~g}$ and females $0.96 \pm 0.58 \mathrm{~g}$. Cross correlation function analysis of GSI and condition factor showed that there was no significant difference $(P>0.05)$ between them (Fig. 5).

The total length of females used for estimation of the first sexual maturity ranged from 7.46 to $14.14 \mathrm{~cm}$ and males from 7.64 to $14.62 \mathrm{~cm}$. Estimated length of sexual maturity was at 8.99
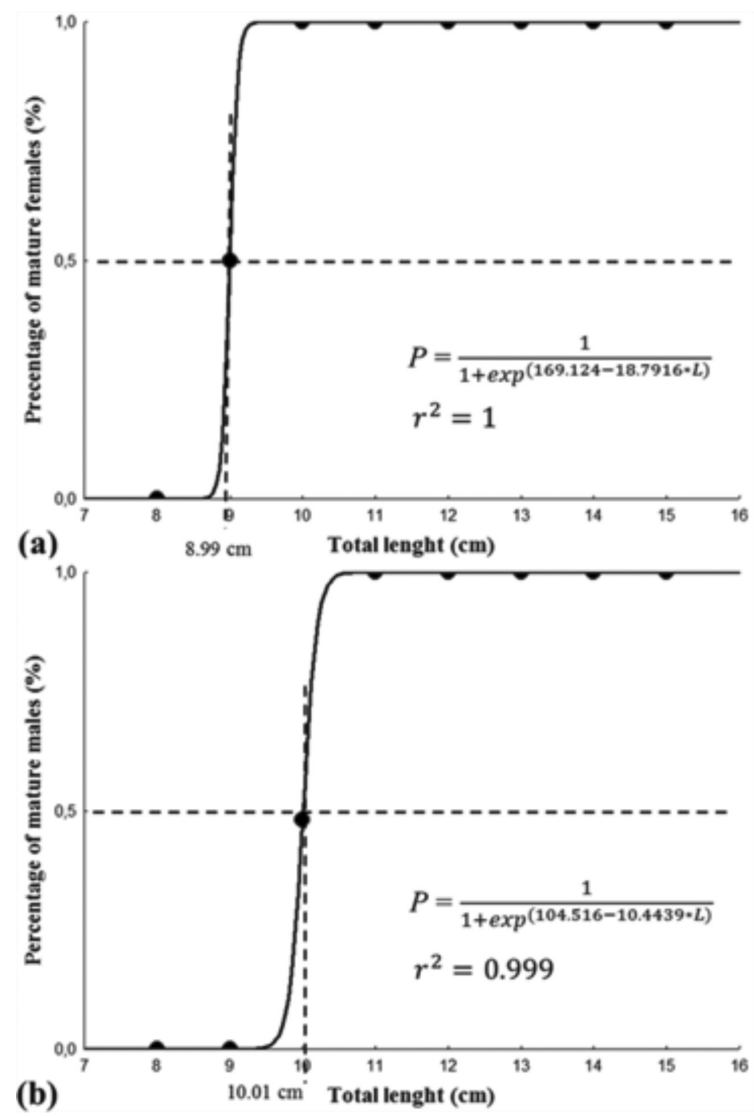

Fig. 6. Total length $(\mathrm{cm})$ of the first sexual maturity calculated for females (a) and males (b) of Lepidotrigla dieuzeidei, southern Adriatic Sea

$\mathrm{cm}$ for females (Fig. 6a) and $10.01 \mathrm{~cm}$ for males (Fig. 6b) which corresponds with ages 1 and 2.

Histological sections of ovaries showed the presence of oocytes in primary growth, cortical alveolar and vitellogenic stage throughout the year. September (Fig. 7a) and October (Fig 7b) are characterized by the increase in number of vittellogenic oocytes. Increase gonadal activity is visible from November (Fig 7c) to February (Fig. 7f) which coincided with the annual increasing of GSI values. During this period number of oocytes in germinal vesicle migration stage started to increase and remained high until June (Fig. 7j). During May, oocytes in germinal vesicle migration and in hydration stage were most dominant, showing that this month represented one of the highest spawning peaks for this species (Fig. 7h) in accordance also to GSI values. The number of these developing stages started to decreases during July (Fig. 7k) and especially in August (Fig. 71) when number of 

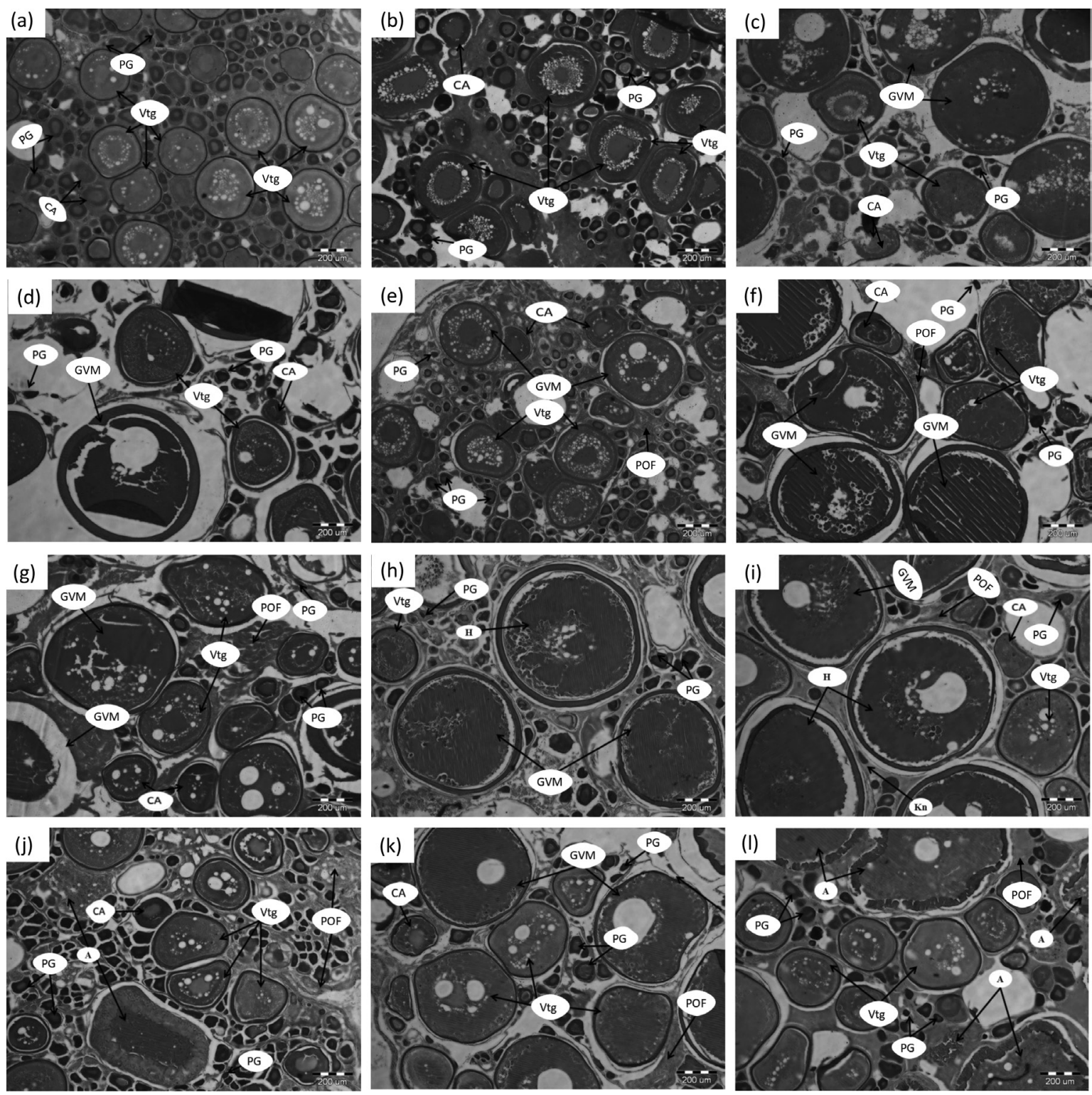

Fig. 7. Photomicrographs of gonad developmental stages in female Lepidotrigla dieuzeidei, throughout the year (September 2011 (a) to August 2012 (l)): PG, primary growth; CA, cortical alveoli; Vtg, vitellogenic oocyte; GVM, germinal vesicle migration; $H$, hydrated oocyte; A, atresic oocyte; POF, post ovulatory follicles. Scale bar: $200 \mu \mathrm{m}$

oocytes in primary growth stage increased and atretic oocytes were visible on sections. Postovulatory follicles were present in ovaries during January (Fig. 7e), February (Fig. 7f), March (Fig. 7g) and in the period from May (Fig. 7i) until August (Fig. 71).

Throughout the whole year, primary growth oocytes with a diameter smaller than $100 \mu \mathrm{m}$ and vitellogenic oocytes with diameter from 100 to $500 \mu \mathrm{m}$ were present in ovaries. Oocytes in germinal vesicle migration (from 500 to 700 $\mu \mathrm{m})$ and hydration $(>700 \mu \mathrm{m})$ stage were not present during September, while the prevalence of these stages occurred from February to June.

Cross correlation function analysis between the monthly average oocyte diameter and monthly GSI showed a positive relationship between the two-time series. Moreover, the analysis showed that the time difference between the increase or decrease of the average oocyte diameter and a similar change of GSI is 1 month (Fig. 8). 


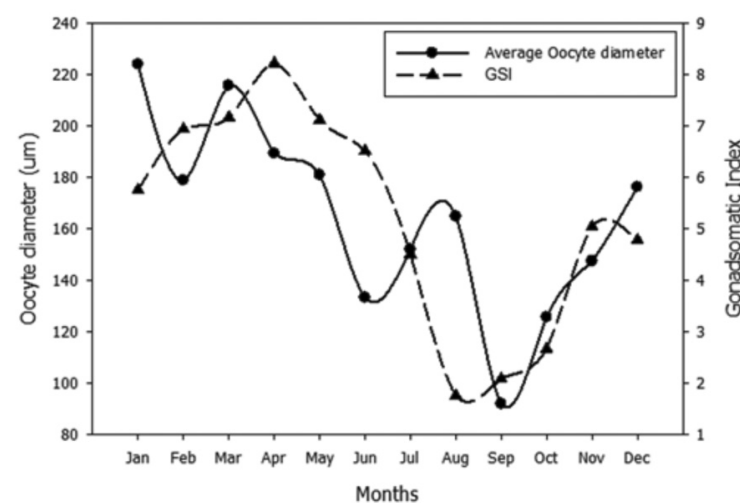

Fig. 8. Monthly comparison of GSI and oocyte diameter $(\mu \mathrm{m})$ of of Lepidotrigla dieuzeidei, southern Adriatic Sea

Only 40 mature females (total length from 9.83 to $13.93 \mathrm{~cm}$ ) fitted the criteria for estimating batch fecundity. The formation of the new batch at the end of spawning showed that annual fecundity of $L$. dieuzeidei is indeterminate. Absolute batch fecundity was estimated to be from 558 to 10230 oocytes per female. Fecundity was positively correlated with total length $\left(\mathrm{F}=1.181^{*} T L^{3.35}, r^{2}=0.750\right.$, Fig. 9a), total weight $\left(\mathrm{F}=252.5^{*} \mathrm{TW}^{1.04}, r^{2}=0.748\right.$, Fig. 9b) and gonad weight $\left(\mathrm{F}=3643.7 * \mathrm{GW}^{0.90}, r^{2}=0.904\right.$, Fig. 9c). The best correlation was established for fecundity-gonad weight relationship $\left(r^{2}=0.904\right)$. Compering fecundity with age, Tukey test (ANOVA) showed that there is significant similarity $(P<0.0001)$ between age 3 and 4 (Fig. 10).

Histological analysis of gonads in mature males showed that spermatocysts of $L$. dieuzei$d e i$ were containing all stages of spermatogenesis including spermatids and spermatozoa throughout the whole year. Presence of the spermatozoa in the lumen of the lobules and in the sperm ducts during September (Fig. 11a) and April (Fig. 11b) indicated spawning capable phase following the peaks in the females spawning season.
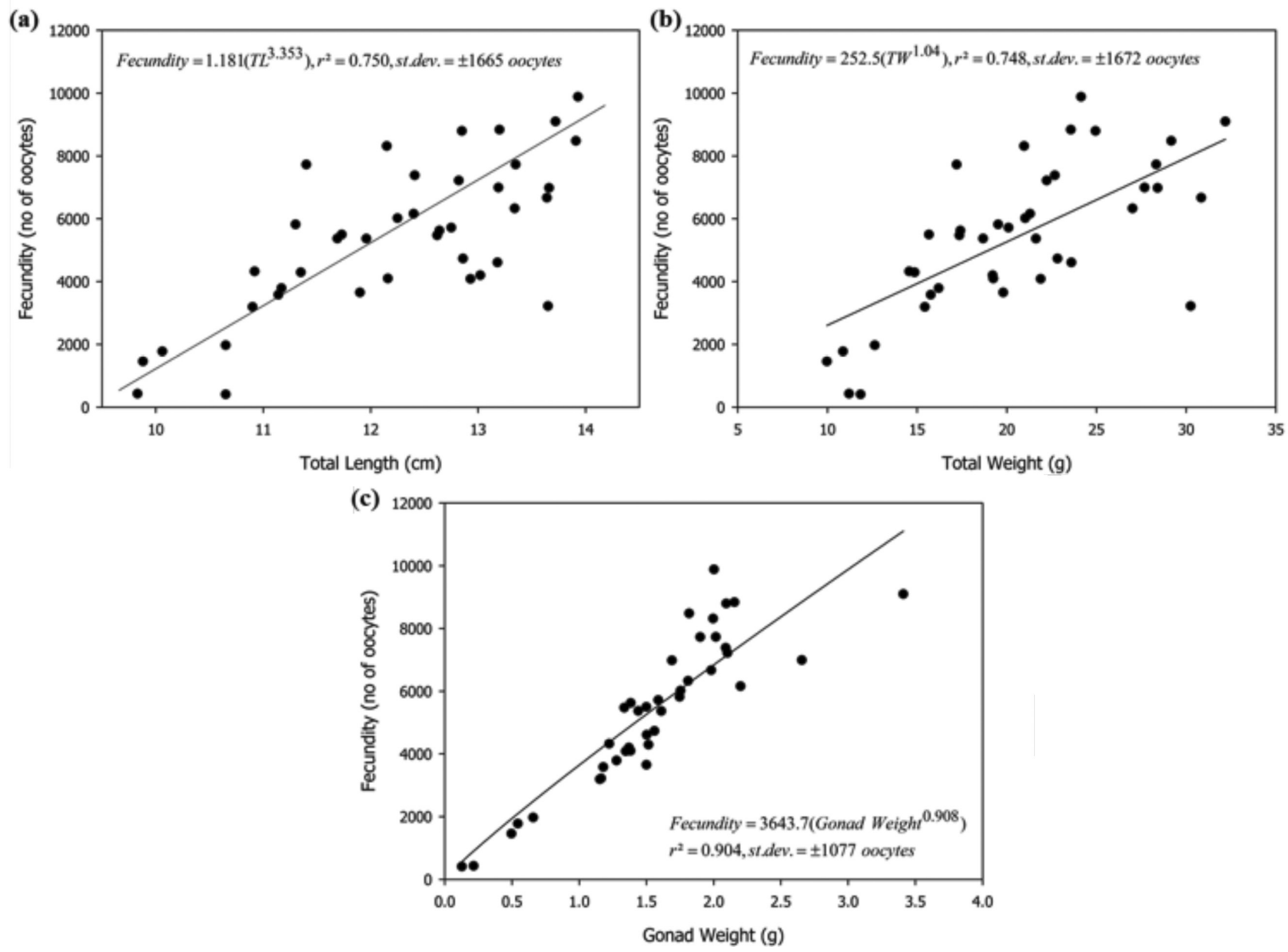

Fig. 9. Relationships between fecundity-length (a), fecundity-weight (b) and fecundity-gonad weight (c) of Lepidotrigla dieuzeidei, southern Adriatic Sea 


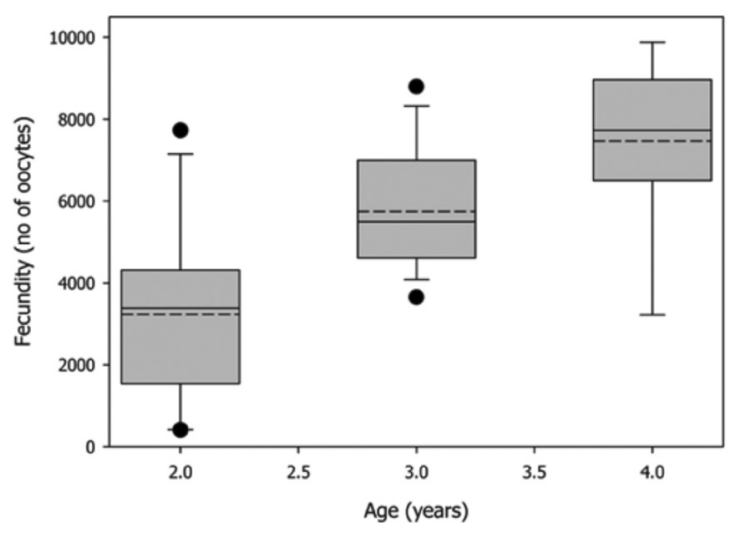

Fig. 10. Relationship between fecundity and female age (dashed line - mean) of Lepidotrigla dieuzeidei, southern Adriatic Sea
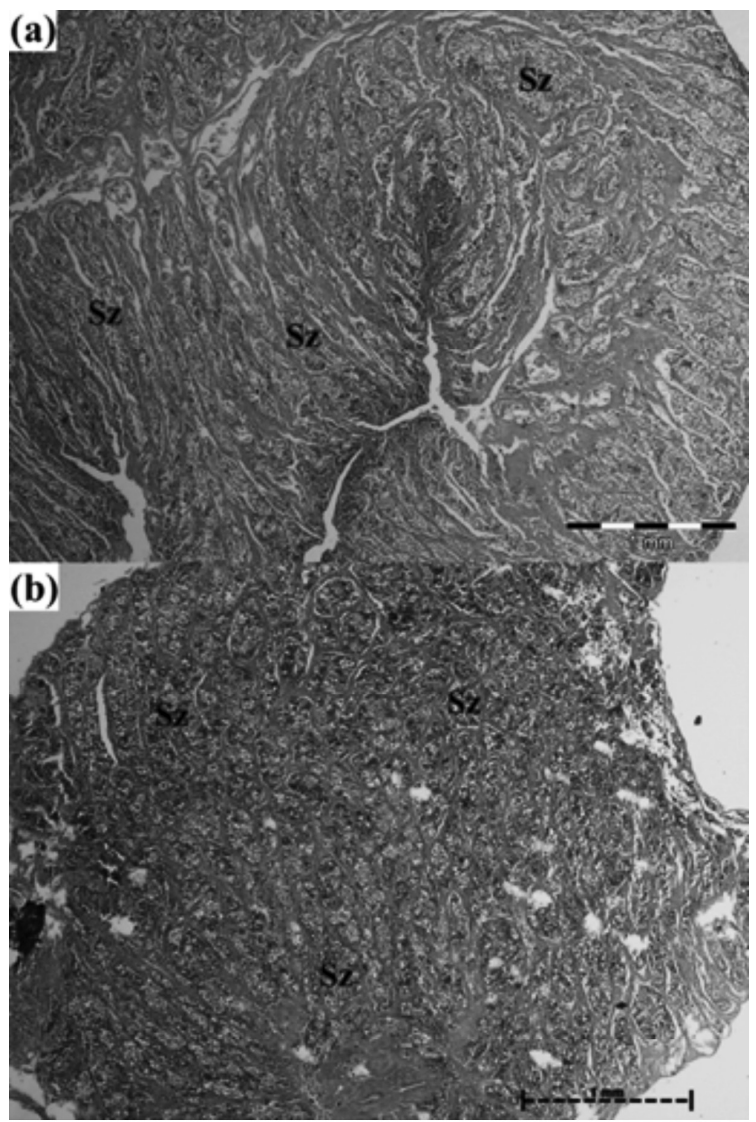

Fig. 11. Histological section of testes in Lepidotrigla dieuzeidei during (a) September and (b) April with high presence of spermatozoa (Sz). Scale bar: $1 \mathrm{~mm}$

\section{DISCUSSION}

This study represents the first detailed description of the reproductive characteristics of $L$. dieuzeidei. This species is considered as by-catch in trawl nets in the Adriatic Sea and therefore fishing effort is one of the key factors influencing the composition of its population.

The selectivity of fishing gear used in this study may be the reason why individuals smaller than $7 \mathrm{~cm}$ were not caught. The total length of analysed individuals ranged from 7.46 to 14.69 $\mathrm{cm}$ which is similar to those obtained in other areas (OLIM \& BORGES, 2006; VALLISNERI, et al. 2011; TORRES et al., 2012). Another reason is that the juveniles of this species, as well as of other species belonging to the family Triglidae, only live in shallow areas and their habitat change is related with growth and reproduction (PAPACONSTANTINOU, 1983; COLLOCA et al., 1994, 1997). The maximum total length of $20.4 \mathrm{~cm}$ was reported in the northeastern Mediterranean (BAŞUSTA et al., 2013a).

The dominance of females recorded in this study was already observed for the majority of species within the Triglidae family (ILHAN \& TOĞULGA, 2007; BOUDAYA et al., 2008; BEN JRAD et al., 2010; MARRIOTT, et al., 2010; VALLISNERI et al., 2011; DOBROSLAVIĆ et al., 2015). Fishing time and used fishing gear can enhance further fluctuation of male to female ratio in the population (RICK$E R, 1973)$. Positive allometry was obtained in this study as well as in previous studies of $L$. dieuzeidei. Equation parameters for females and males from different studies are given in Table 1.

Females had higher values of condition factor due to higher gonad weight. Higher values for females (1.39) than males (1.21) were also recorded in the study of OLIM \& BORGES (2006). BAŞUSTA et al. (2013a) obtained smaller values of condition factor for females (0.80) than males (0.81) which they related to gonadal development. Results from this study showed that values followed the reproductive cycle with lower values recorded during the spawning period. High and low values were recorded both at higher and smaller total lengths indicating spawning and maturation. 
Table 1. Length-weight relationship equation constant of Lepidotrigla dieuzeidei from different locations

\begin{tabular}{llcccc}
\hline \multicolumn{1}{c}{ Authors } & \multicolumn{1}{c}{ Location } & Sex & $a$ & $b$ & $\mathrm{R}^{2}$ \\
\hline \multirow{2}{*}{ Olim and Borges (2006) } & South coast of Portugal & $\mathrm{F}$ & 0.011 & 3.04 & 0.87 \\
& & $\mathrm{M}$ & 0.009 & 3.11 & 0.96 \\
Vallisneri et al. (2010) & Adriatic Sea & $\mathrm{F}$ & 0.005 & 3.27 & 0.95 \\
& & $\mathrm{M}$ & 0.006 & 3.31 & 0.96 \\
Başusta et al. (2013) & northeast Mediterranean Sea & $\mathrm{F}$ & 0.003 & 3.41 & 0.84 \\
& & $\mathrm{M}$ & 0.004 & 3.28 & 0.81 \\
This study & Adriatic Sea & $\mathrm{F}$ & 0.082 & 3.11 & 0.90 \\
& & $\mathrm{M}$ & 0.009 & 3.04 & 0.93 \\
\hline
\end{tabular}

Earlier sexual maturation of males is common in the majority of species including the family Triglidae. (PAULY, 1978, 1994; PAPACONSTATINOU, 1984). This was recorded for tub gurnard Chelidonichthys lucerna (ILHAN \& TOĞULGA, 2007; BOUDAYA et al., 2008; VALLISNERI et al., 2011; ELSERAFY et al., 2015), red gurnard Chelidonichthys cuculus (VALLISNERI et al., 2014) and longfin gurnard Chelidonichthys obscurus (MUÑOZ et al., 2001; MUÑOZ et al., 2003). In this study female of L. dieuzeidei reach sexual maturity at a smaller total length $(8.99 \mathrm{~cm})$ compared to males $(10.01$ $\mathrm{cm})$. Earlier maturation of females is usually observed in populations with a smaller number of males than females (BAYLIS, 1981). Maturation of females at smaller total lengths than males is also recorded for streaked gurnard, Chelidonichthys lastoviza (BEN JARD et al., 2010). Length at first maturity is a good indicator of species vulnerability to fishing impact (ANDERSON et al., 2008) as over-exploitation of immature individuals could have a negative impact on the population resilience and recruitment (MYERS et al., 1997).

L. dieuzeidei in the south Adriatic shows a prolonged spawning period (November to July), which is common among gurnards (LEWIS \& YERGER, 1976; MCBRIDE \& ABLE, 1994). This observation is in accordance with the results of a previous study on L. cavillone in the Adriatic Sea which reported maximum gonadal activity between January and August (DOBROSLAVIĆ et al., 2015). According to available literature spawning period in other Triglidae is shorter (MUÑOZ et al., 2001; MUÑOZ et al., 2003; İLHAN \& TOĞULGA, 2007; BOUDAYA et al., 2008; VALLISNERI et al., 2014;
EL-SERAFY et al., 2015) than those recorded for species of gender Lepidotrigla in the Adraitic Sea. Also, the male gonads of $L$. dieuzeidei were found significantly smaller than female gonads; the same characteristic was observed in previous studies of L. cavillone (COLLOCA et al., 1997; İLKAYAZ et al., 2010; DOBROSLAVIĆ et al., 2015).

The reproductive cycle was assessed using standard qualitative and quantitative histological techniques as the primary method for staging gonadal development. Based on monthly gonad analysis, this study showed that $L$. dieuzeidei has multiple synchronous development of ovaries with multiple spawning events. This was also recorded for longfin gurnard $C$. obscura (MUÑOZ et al., 2001) and large-scaled gurnard $L$. cavillone (DOBROSLAVIĆ et al., 2015). The ovaries were always represented with a group of primary oocytes and a diverse population of vitellogenic oocytes, which are each specially recruited during the final stages of maturation in uniform or uneven phases. Also, postovulatory tissue in the gonads with vitellogenic oocytes supports the previous statement that the species spawns several times within the spawning period. Multiple spawning is a strategy to increase larvae survival (LAMBERT \& WARE, 1984) and it also occurs in species with high fecundity and a physical limitation (small size), since hydration significantly increases the diameter of the eggs and expands the abdominal cavity (BEGENAL, 1973; FORDHAM \& TRIPPEL, 1999). Atresia is influenced by several external factors, temperature changes, lack of food and stress being the most important ones (GURAYA \& SAUER, 1986). Since this species lives at depths were the external factor are stabile we 
assume that a high number of atretic oocytes is the natural process of regulating final fecundity. Atresia has been described as a regulation process to maintain ovary homeostasis and it represents the ratio between the number and size of oocytes and the available energy sources (LUCKENBACH et al., 2008).

A quantitative method of measuring the size of oocytes (expressed as oocyte diameter) was also employed in this study and it followed the pattern observed using qualitative histological methods. The maximum oocyte diameter recorded for $L$. dieuzeidei was $946.05 \mu \mathrm{m}$, which coincides with the maximum size report for L. cavillone at $974.85 \mu \mathrm{m}$ (DOBROSLAVIĆ et al., 2015). The quantitative analysis of female gonads showed a continuous representation of all oocyte sizes throughout the year with no visible gaps between the first and the second stage of development, meaning that previtellogenic and vitellogenic oocytes were always present in the gonads.

The continuous first and second developmental stage of oocytes indicate the indeterminate type of fecundity (for this species, with a prolonged spawning period and spawning occurring several times in a year HUNTER \& MACEWICZ, 1985b; WEST, 1990). Species that have such indefinite fecundity continuously produce new oocytes for the entire period of spawning, and as such, it greatly depends on environmental factors (e.g. temperature and food availability) and the overall length and weight of the body (HUNTER et al., 1985).

L. dieuzeidei has a lobular type of testes, recorded also for other triglids (MUÑOZ et al., 2001; DOBROSLAVIĆ et al., 2015). The analysis from this study showed that male gonads were at the spawning stage almost all year round, with spermatogenetic cells in different developmental stages. This indicates a long spawning period of several months to one year (SCHULZ et al., 2010).

By-catch species have an important role in the energy flow and uncontrolled harvesting of these species can have negative consequences especially in the oligotrophic seas such as Adriatic. To be able to answer the question is this type of reproduction characteristic for $L$. dieuzeidei or it is the answer to a high fishing effort future monitoring of this species is required.

\section{REFERENCES}

ANDERSON, C.N.K., C-h. HSIEH, S.A. SANDIN, R. HEWITT, A. HOLLOWED, J. BEDDINGTON, R.M. MAY \& G. SUGIHARA. 2008. Why fishing magnifies fluctuations in fish abundance. Nature, 452: 835-839.

BAÑóN, R. 2004. New records of two southern fish in Galician waters (NW Spain). Cybium, 28(4): 367-368.

BAŞUSTA, A., N. BAŞUSTA, M. CALTA, R.I. OZER \& H. GIRGIN. 2013a. Length-weight relationship and condition factor of spiny gurnard (Lepidotrigla dieuzeidei Blanc and Hureau, 1973) inhabiting Northeast Mediterranean Sea. J. Anim. Vet. Adv., 12(2): 212-214.

BAȘUSTA, A., E.I. ÖZER \& H. GIRGIN. 2013b. Relationship between fish length and otolith dimensions in the population of Lepidotrigla dieuzeidei (Blanc \& Hureau, 1973) from Mediterranean. Yunus Araștirma Bülteni, 3: 3-9.
BAŞUSTA, A., N. BAŞUSTA, M. CALTA \& E.I. OZCAN, 2017. A study on age and growth characteristics of spiny gurnard (Lepidotrigla dieuzeidei Blanc \& Hureau, 1973), northeastern Mediterranean Sea. J. Appl. Ichthyol., 33(5): 966-970.

BAYLIS, J.R. 1981. The evolution of parentl care in fishes, with reference to Darvin's rule of male sexual selection. Environ. Biol. Fish., 6: 223-251.

BEGENAL, T.B. 1973. Fish fecundity and its relations with stock and recruitment. Rapports et Proce's-Verbaux des Re'unions du Conseil International pour 1'Exploration de la Mer, 164: 186-198.

BAGENAL, T.B. 1978. Aspects of fish fecundity. Halsted Press New York, pp. 75-101.

BEN JRAD, L., R. FEHRI-BEDOUI, S. BEN SLAMA \& O.K. BEN HASSINE. 2010. Reproduction and diet of Trigloporus lastoviza (Triglidae) in 
the Gulf of Tunis. Cybium 34(4): 353-365. BOUDAYA, L., L. NEIFAR, P. RIZZO, C. BADALUCCO, A. BOUAIN \& F. FIORENTINO. 2008. Growth and reproduction of Chelidonichthys lucerna (Linnaeus) (Pisces: Triglidae) in the Gulf of Gabès Tunisia. J. Appl. Ichthyol., 24: 581588.

BROWN-PETERSON, N.J., D.M. WYANSKI, F. SABORIDO-REY, B.J. MACEWICZ \& S.K. LOWERREBARBIER. 2011. A Standardized Terminology for Describing Reproductive Development in Fishes. Mar. Coast. Fish., 3: 52-70.

CADDY, J.F. 1993. Some future perspectives for assessment and management of Mediterranean fisheries. Sci Mar 57(2-3):121-130

COLLOCA, F., G.D. ARDIZZONE \& M.F. GRAVINA. 1994. Tropic ecology of gurnards (Pisces: Triglidae) in the Central Mediterranean Sea. Mar. Lif., 32: 21-31.

COLLOCA. E., M. CARDINALE \& G.D. ARDIZZONE. 1997. Biology, spartial distribution and population dynamics of Lepidotrigla cavillone (Pisces: Triglidae) in the Central Tyrrhenian Sea. Fish. Res., 32: 21-32.

DALYAN, C. \& L. ERYILMAZ. 2006. Two new fish from Turkish coast of the Eastern Mediterranean: the garfish, Belone svetovidovi Collette and Parin, 1970; the spiny gurnard, Lepidotrigla dieuzeidei Audoin in Blanc and Hureau, 1973. J. Black Sea/Mediterranean Environ., 12: 155-158.

DOBROSLAVIĆ, T., J. SULIĆ ŠPREM, I. PRUSINA, V. KOŽUL, B. GLAMUZINA \& V. BARTULOVIĆ. 2015. Reproduction biology of large-scaled gurnard Lepidotrigla cavillone (Lacepède, 1801) from the southern Adriatic Sea (Croatia). J. Appl. Ichthyol. 31: 49-53.

EL-SARAFY, S.S., F.I. EL-GAMMAL, S.F. MEHANNA, N-AH. ABDEL-HAMID \& F.E. FARRAG .2015. Age, Growth and Reproduction of Tub Gurnard, Chelidonichthys lucerne (Linnaeus, 1758) from the Egyptian Mediterranean waters off, Alexandria. International J. Fish. Aquat. Sci., 4: 13-20.

ERYILMAZ, L. 2002. The spiny gurnard, Lepidotrigla dieuzeidei Audoin in Blanc \& Hureau, 1973, new to the Sea of Marmara. Isr. J. Zoo., 48(3): 245-245.
FORDHAM, S.E. \& E.A. TRIPPEL. 1999. Feeding behaviour of cod (Gadus morhua) in relation to spawning. J. Appl. Ichthyol., 15: 1-9.

FROESE, R. 2006. Cube law, condition factor and weight-length relationships: history, metaanalysis and recommendations. J. Appl. Ichthyol., 22: 241-253.

GRIER, H.J. 1981. Cellular organization of the testis and spermatogenesis in fishes. Am. Zool. 21: 345-357.

GURAYA, S. \& H.W. SAUER. 1986. The cell and molecular biology of fish oogenesis. In: Monographs in Developmental Biology. Vol. 18, S. Karger Publisher, New York, pp. 232.

HUNTER, J.R. \& B. MACEWICZ. 1985a. Rates of atresia in the ovary of captive and wild northern anchovy, Engraulis mordax. Fish. Bull., 83: 119-136.

HUNTER, J.R. \& B. MACEWICZ. 1985b. Measurement of spawning frequency in multiple spawning fishes. In: Lasker, R. (Editor) An Egg Production Method for Estimating Spawning Biomas of Pelagic Fish: Application to the Northen Anchovy, Engraulis mordax. NOAA Tech. Rep. NMFS 36, pp. 79-94.

HUNTER, J.R., N.C.H. LO, R. LEONG \& B. MACEWICZ. 1985. Batch fecundity in multiple spawning fishes. In: Lasker, R. (Editor). An Egg Production Method for Estimating Spawning Biomas of Pelagic Fish: Application to the Northen Anchovy, Engraulis mordax. NOAA Tech. Rep. NMFS. 36, pp. 67-78.

İLHAN, D. \& M. TOĞULGA. 2007. Age, growth and reproduction of tub gurnard Chelidonichthys lucernus, Linnaeus, 1758 (Osteichthtyes: Triglidae) from İzmir Bay, Aegean Sea, Easter Mediterranean. Acta Adriat., 48(2): 173-184.

ILKYAZ, A.T., G. METIN, O. SOYKAN \& H.T. KINACIGIL. 2010.Growth and reproduction of large-scaled gurnard (Lepidotrigla cavillone Lacepède, 1801) (Triglidae) in the central Aegean Sea, eastern Mediterranean. Turk. J. Zool., 34(4): 471-478.

JARDAS, I. 1996. Jadranska Ihtiofauna. Školska Knjiga, Zagreb, pp. 533.

LAMBERT, T.C. \& D.M. WARE. 1984. Reproductive strategies of demersal and pelagic spawning 
fish. Can. J. Fish. Aquat. Sci., 41(11): 15651569.

LEWIS, T.C. \& R.Z. YERGER. 1976. Biology of 5 species of searobins (Triglidae) from the Northeastern Gulf of Mexico. Fish. Bull., 74: 93-103.

LUCKENBACH, J., D. ILIEV, F. GOETZ \& P. SWANSON. 2008. Identification of differentially expressed ovarian genes during primary and early secondary oocyte growth in coho salmon, Oncorhynchus kisutch. Reprod. Biol. Endocrin., 6(1): 2-16.

MACER, C.T. 1974. The reproductive biology of the horse mackerel Trachurus trachurus (L.) in the North Sea and English Channel. J. Fish. Biol., 6: 415-438.

MARRIOTT, A.L., J.W. LATCHFORD \& I.D. MCCATHY. 2010. Population biology of the red gurnard (Aspitrigla cuculus L.; Triglidae) in the inshore waters of Eastern Anglesey and Northwest Wale. J. Appl. Ichthyol., 26: 504512.

MCBRIDE, R.S. \& K.W. ABLE. 1994. Reproductive seasonality, distribution and abundance of Prionotus carolinus and P. evolans (Pisces: Triglidae) in the New York bight. East. Coast. Shelf. Sci., 38: 173-188.

MONTANINI, S., M. STAGIONI \& M. VALLISNERI. 2010. Elliptic fourire analysis of otoliths of Triglidae in the north-middle Adriatic Sea. Biol. Mar. Mediterr., 17(1): 346-347.

MUÑOZ, M., M. CASADEVALL \& S. BONET. 2001. Gonadal structure and gametogenesis of Aspitrigla obscura (Pisces, Triglidae). Ital. J. Zool. 64: 39-46.

MUÑOZ, M, M.R. HERNÁNDEZ, M. SÀBAT \& M. CASADEVALL. 2003. Annual reproductive cycle and fecundity of Aspitrigla obscura (Teleostei, Triglidae). Vie et Milieu, 53: 123129.

MYERS, R.A., J.A. HUTCHINGS \& N.J. BARROWMAN. 1997. Why do fish stocks collapse? The example of cod in Atlantic Canada. Ecol. Appl., 7(1): 91-106.

NCSS 11 Statistical Software (2016). NCSS, LLC. Kaysville, Utah, USA, ncss.com/software/ ncss.

OLIM, S. \& T.C. BORGES. 2006. Weight-length relationship for eight species of the family Trigli- dae discarded on the south coast of Portugal. J. Appl. Ichthyol., 22(4): 257-259.

PAPACOSTANTINOU, C. 1983. Observations on the ecology of gurnards (Pisces: Triglidae) in Greek Seas. Cybium, 7: 71-81.

PAPACONSTATINOU, C. 1984. Age and growth of the yellow gurnard (Trigla lucerna L. 1758) from the Thermaikos Gulf (Greece) with some comments on its biology. Fish. Res., 2: 243-255.

PAULY, D. 1978. A preliminary compilation of fish length growth parameters. Berichte des Institut für Meereskunde an der ChristianAlbrechts Universität Kiel 55, pp. 200.

PAULY, D. 1994. On the sex of fish and the gender of scientists. Chapman and Hall, London, pp. 250.

RICKER, W.E. 1973. Linear regressions in fishery research. J. Fish. Res. Board. Can., 30: 409434.

RICKER, W.E. 1977. Computation and interpretation of biological statistics of fish population. B. Fish. Res. Board. Can., 191: 382.

SÁNCHEZ, P. P. SARTOR, L. RECASENS, A. LIGAS, J. MARTIN, S. DE RANIERI \& M. DEMESTRE. 2007. Trawl catch composition during different fishing intensity periods in two Mediterranean demersal fishing grounds. Sci. Mar., 71(4): 765-773.

SCHULZ, R.W., L.R. DE FRANÇA, J.J. LAREYRE, F. LEGAC, H. CHIARINI-GARCIA, R.H. NOBREGA \& T. MIURA. 2010.Spermatogenesis in fish. Gen. Comp. Endocr. 165(3): 390-411.

SPARRE P. \& S.C. VENEMA. 1998. Introduction to tropical fish stock assessment. Part 1. Manual. FAO Fisheries Technical Paper. No. 306/1, Rev.2. Rome, FAO, pp. 407.

TAKASHIMA, F. \& T. HIBIYA. 1995. An atlas of fish histology. Normal and pathological Features, $2^{\text {nd }}$ ed. Kodansha Ltd., Tokyo, pp. 195.

TOMLINSON, P.K. \& J. NORMAN. 1961. Fitting A von Bertalanffy Growth Curve by Least Squares Including Tables of Polynomials. Fish. Bul., pp. 70.

TORRES, M.A., F. RAMOS \& I. SOBRINO. 2012. Length-weight relationships of 76 fish species from the Gulf of Cadiz (SW Spain). Fish. Res., 127-128: 171-175. 
TYLER, C.R. \& J.P. SUMPTER J.P.1996. Oocyte growth and development in teleosts. Rev. Fish. Biol. Fisher., 6: 287-318.

VALLISNERI, M., M. STAGIONI, S. MONTANINI \& S. TOMMASINI. 2011. Body size, sexual maturity and diet in Chelidonichthys lucerna (Osteichthyes: Triglidae) from the Adriatic Sea, north eastern Mediterranean. Acta Adriat., 51(1): 141-148.

VALLISNERI, M., S. TOMMASINI, M. STAGIONI, C. MANFFREDI, I. ISAJLOVIĆ \& S. MONTANINI.
2014. Distribution and some biological parameters of the red gurnard Chelidonichthys cuculus (Actinopterygii, Scorpaeniformes, Triglidae) in the north-central Adriatic Sea. Acta Ichthyol. Piscat., 44: 173-180.

WALLACE, R.A. \& K. SELMAN. 1981. Cellular and dynamic aspects of oocyte growth in teleosts. Am. Zool., 21: 325-343.

WEST, G. 1990. Methods of assessing ovarian development in fishes: a review. Aust. J. Mar. Fresh. Res., 41: 199-222.

Received: 30 October 2020

Accepted: 7 April 2021 


\title{
Reproduktivna strategija kokotića, Lepidotrigla dieuzeidei Blanc and Hureau, 1973 iz jugoistočnog dijela Jadranskog mora
}

\author{
Tatjana DOBROSLAVIĆ* , Alexis CONIDES, Jadranka SULIĆ ŠPREM, \\ Branko GLAMUZINA i Vlasta BARTULOVIĆ \\ *Kontakt adresa,e-mail: tatjana.dobroslavic@unidu.hr
}

\begin{abstract}
SAŽETAK
Ovo istraživanje donosi prve podatke o reproduktivnoj biologiji kokotića, Lepidotrigla dieuzeidei. Ukupno je prikupljeno 1027 jedinki, uzorkovano je mjesečno od rujna 2011. do kolovoza 2012. Ukupna duljina jedinki bila je u rasponu od 7,46 cm do 14,62 cm s omjerom spolova ženke:mužjaci 1:0,59. Pozitivan alometrijski rast zabilježen je i kod ženka $(b=3,07)$ i kod mužjaka $(b=3,08)$. Promjene indeksa kondicije bile su slične kod oba spola sa srednjim vrijednostima od 1,07 za ženke i 1,01 za mužjake. Temeljem mjesečnih vrijednosti gonadosomatskog indeksa utvrđeno je da kokotić ima dugo razdoblje mriješćenja, od studenog do srpnja. Histološka analiza pokazala je multipli sinkroni razvoj jajnika s više razdoblja mriješćenja. U jajnicima su uvijek bile zastupljene skupine primarnih oocita i raznovrsni stadiji vitelogenih oocita, koji su regrutirani u posljednjim stadijima sazrijevanja u jednoličnim ili neravnomjernim fazama. Fekunditet je procijenjen gravimetrijski primjenom metode hidratiziranih oocita i iznosi oko 558 do 10230 oocita po ženki. Kokotić je važna vrsta u prilovu i podatci iz ovog istraživanja predstavljaju značajan doprinos upravljanja stockom.
\end{abstract}

Ključne riječi: oogeneza; spermatogeneza; sazrijevanje gonada; plodnost; promjer oocita; višestruko mriješćenje ribe 